\section{UNIVERSITY \\ of DEBRECEN}

FACULTY OF

HEALTH

NYÍREGYHÁZA

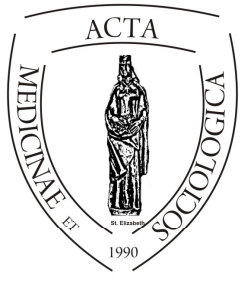

ACTA

MedSoc

VOLUME 5.

2014

\title{
Lakásjellemzők Nyíregyházán 2012
}

\author{
Szoboszlai Katalin \\ Debreceni Egyetem, Egészségügyi Kar, \\ Szociális és Társadalomtudományi Intézet
}

\begin{abstract}
The third survey done "Nyíregyháza quality of life - household panel" study (hereinafter referred to as panel study) in 2012. Data on the housing had to be considered when analyzing the structural condition into account that the housing stock is a slight change our town and in the country as well. In fact, there is hardly any growth in the housing stock is characterized by the relative recorded in 2008 and 2010 data in Nyíregyháza in 2012.

No changes to the ownership structure draws attention to the still limited number of rental housing in the city. The existing rental housing especially in poor districts carry the characteristics of poverty housing.
\end{abstract}

Keywords: inhabitants, housing, rental housing, housing poverty

DOI: $10.19055 / \mathrm{ams} .2014 .5 / 12-13 / 7$

\section{Bevezetés}

A harmadik adatfelvétel történt meg „Nyíregyháza életminősége - háztartáspanel” vizsgálatban (továbbiakban: panel vizsgálat) 2012-ben. A lakásokra vonatkozó elemzésekor számításba kellett venni azt a strukturális körülményt, miszerint a lakásállomány az országban és városunkban is kis mértékben változik. Tény, hogy alig tapasztalható növekedés jellemzi a lakásállományt a 2008-ban és 2010-ben felvett adatokhoz képest Nyíregyházán. Éppen e miatt a lakónépes- 
ség és a lakásállomány bemutatásához a 2008, 2010 és 2012. évi nyíregyházi panelkutatás statisztikai adatai mellett a 2011. évi népszámlálás megyeszékhelyre vonatkozó adatait használom fel.

\section{A lakónépesség és a lakások számának alakulása Nyíregyházán}

Nyíregyháza állandó lakónépességének száma enyhén növekvő tendenciát mutat, 2001 és 2011 között megközelítően 951 fővel, 1 százalékkal emelkedett az állandó lakónépesség száma a megyeszékhelyen. A lakások számában azonban számottevő növekedést tapasztalhatunk, tíz év alatt 7129 db lakás épült a városban, ami 16 százalékos emelkedést mutat a vizsgált időszakban. A népszámlálási adatok alapján a vizsgált évtizedben az újonnan épült lakások 86 százaléka, 6151 lakás épült 2008-ig, ezt követően 1200 lakással bővült a lakásállomány a városban.

\begin{tabular}{|c|c|c|}
\hline Év & Állandó népesség száma (fö) & Lakások száma (db) \\
\hline $\mathbf{2 0 0 1}$ & $\mathbf{1 1 8 7 9 5}$ & $\mathbf{4 4 1 4 5}$ \\
\hline 2008 & 118874 & 50296 \\
\hline 2010 & 119094 & 51057 \\
\hline $\mathbf{2 0 1 1}$ & $\mathbf{1 1 9 7 4 6}$ & $\mathbf{5 1 2 7 4}$ \\
\hline
\end{tabular}

1. sz. tábla: A lakónépesség és a lakások számának változása 2001-2011.

Forrás: KSH, 2001. és 2011. évi népszámlálási adatok és városadatok.

A megyei jogú városok (MJV) tekintetében Nyíregyházán a legmagasabb az ezer lakosra jutó épített lakások száma 2001 és 2010. között. A MJV átlag 3,7, ehhez képest városunkban 6,8 épített lakás jut 1000 lakosra, ezzel az első helyen áll a település a lakásépítésben, megelőzve olyan nagyobb lakosságszámú településeket, mint Debrecen és Miskolc. (KSH, 2012. Megyei jogú városok) 


\begin{tabular}{|c|c|c|c|c|c|}
\hline Lakott & $\begin{array}{c}\text { Nem } \\
\text { lakott }\end{array}$ & \multirow[t]{2}{*}{$\begin{array}{c}\text { Összes } \\
\text { lakás }\end{array}$} & Lakott & $\begin{array}{c}\text { Nem } \\
\text { lakott }\end{array}$ & \multirow[t]{2}{*}{ Összes } \\
\hline \multicolumn{2}{|c|}{ lakások száma } & & \multicolumn{2}{|c|}{$\begin{array}{l}\text { lakás a 2001. évi } \\
\text { százalékában }\end{array}$} & \\
\hline 46479 & 4795 & 51274 & 114,5 & 137,1 & 116,3 \\
\hline
\end{tabular}

2. sz. tábla: A lakott és nem lakott lakások Nyíregyházán, 2011.

Forrás: KSH, 2011. évi népszámlálási adatok

A 2011. évi népszámlálás időpontjában a lakásállomány 89,7 százaléka lakott volt, a fennmaradó 10,3 százalék, vagyis minden tizedik lakás üresen állt a városban. Összehasonlítva a 2011. évi adatokat a 2001. évi népszámlálási adatokkal azt látjuk, hogy a lakott lakások arányában kisebb a növekmény, míg a nem lakott lakások száma tíz év alatt 37 százalékkal emelkedett. Az adatokból nem derül ki, mely városrészeken maradtak üresen a lakások, milyen állapotban vannak, és kihez tartoznak ezek a lakások. Fontos lenne odafigyelni ezekre a lakásokra, mivel a hajléktalanok otthonteremtésének alternatívái lehetnek azok a lakások, amelyek felújítás után a lakhatásból tartósan kirekesztődött emberek számára bérleményként számításba vehetőek.

\begin{tabular}{|c|c|c|c|c|c|c|}
\hline & \multicolumn{3}{|c|}{ 2001 } & \multicolumn{3}{c|}{$\mathbf{2 0 1 1}$} \\
\hline \multirow{4}{*}{$\begin{array}{c}\text { Lakásállo- } \\
\text { ebból }\end{array}$} & \multicolumn{3}{|c|}{$\begin{array}{c}\mathbf{5 1 . 2 7 4} \\
\text { ebból }\end{array}$} \\
\cline { 2 - 7 } $\begin{array}{c}\text { (lakás és } \\
\text { lakott üdülö } \\
\text { összesen) }\end{array}$ & $\begin{array}{c}\text { Természetes } \\
\text { személy } \\
\text { tulajdona }\end{array}$ & $\begin{array}{c}\text { Önkor- } \\
\text { mányzati } \\
\text { tulajdonú }\end{array}$ & Egyéb & $\begin{array}{c}\text { Természe- } \\
\text { tes sze- } \\
\text { mély } \\
\text { tulajdona }\end{array}$ & $\begin{array}{c}\text { Önkor- } \\
\text { mányzati } \\
\text { tulajdonú }\end{array}$ & Egyéb \\
\cline { 2 - 7 } & $\begin{array}{c}42124 \mathrm{db} \\
95,4 \%\end{array}$ & $\begin{array}{c}1677 \mathrm{db} \\
3,7 \%\end{array}$ & $\begin{array}{c}271 \mathrm{db} \\
0,6 \%\end{array}$ & $\begin{array}{c}48908 \mathrm{db} \\
95,3 \%\end{array}$ & $\begin{array}{c}1822 \mathrm{db} \\
3,5 \%\end{array}$ & $\begin{array}{c}544 \mathrm{db} \\
1,06 \%\end{array}$ \\
\hline
\end{tabular}

3. sz. tábla: A lakások tulajdona Nyíregyházán 2001-2011.

Forrás: KSH, népszámlálási adatok, 2001 és 2011.

A lakások tulajdoni szerkezetében nem tapasztalható számottevő változás tíz év alatt a városban. Kiemelkedően magas a természetes személy tulajdonában lévő lakások aránya az összes lakást figyelembe véve. Az önkormányzati tulajdonú bérlakásoknál csekély emelkedés látható az adatokban, 145 lakással volt több 2011-ben, mint korábban. Ez az emelkedés fejlődést mutat, azonban nem oldja 
meg azoknak a lakosoknak a gondjait, akik bérlakásban szeretnének élni, úgymint fiatal házasok, kisgyerekes, alacsony keresetủ családok, lakhatási szegénységben élők vagy éppen hajléktalanok. E lakossági csoportokhoz tartozók igényei eltérőek a bérlemények minőségét tekintve, azonban mindenkinél szükséglethiányként jelentkezik a jövedelemhez képest megfizethető bérlakás az otthonteremtés tekintetében.

\begin{tabular}{|c|c|c|c|c|c|c|c|c|c|c|c|}
\hline \multicolumn{6}{|c|}{ Használat jogcíme 2001.} & \multicolumn{6}{|c|}{ Használat jogcíme 2011.} \\
\hline \multicolumn{2}{|c|}{ Tulajdonosi } & \multicolumn{2}{|c|}{$\begin{array}{l}\text { Bérleti, } \\
\text { szolgálati }\end{array}$} & \multicolumn{2}{|c|}{ Egyéb } & \multicolumn{2}{|c|}{ Tulajdonosi } & \multicolumn{2}{|c|}{$\begin{array}{l}\text { Bérleti, } \\
\text { szolgálati }\end{array}$} & \multicolumn{2}{|c|}{ Egyéb } \\
\hline $\begin{array}{c}37280 \\
\text { db }\end{array}$ & $\begin{array}{c}84,5 \\
\%\end{array}$ & $\begin{array}{c}3308 \\
\mathrm{db}\end{array}$ & $\begin{array}{l}7,5 \\
\%\end{array}$ & $\begin{array}{c}187 \\
\mathrm{db}\end{array}$ & $\begin{array}{c}0,4 \\
\%\end{array}$ & $\begin{array}{c}41984 \\
\text { db }\end{array}$ & $\begin{array}{c}81,8 \\
\%\end{array}$ & $\begin{array}{c}3879 \\
\mathrm{db}\end{array}$ & $\begin{array}{l}7,5 \\
\%\end{array}$ & $\begin{array}{c}616 \\
\mathrm{db}\end{array}$ & $\begin{array}{l}1,2 \\
\%\end{array}$ \\
\hline
\end{tabular}

4. sz. tábla: A lakásállomány használati jogcíme Nyíregyházán 2001 és 2011. Forrás: KSH, népszámlálási adatok 2001 és 2011.

A 2001. évi népszámlálási adatok alapján a lakásállomány 84 százalékában maga a tulajdonos lakott, míg a bérleti, szolgálati jogcímen lakott lakások aránya 7,5 százalék volt a városban. A 2011. évi népszámlálási adatok nem mutatnak eltérést a tíz évvel korábbi adatoktól a bérleményben élők arányát tekintve. A 191 ezer lakott lakásból mindösszesen 4 ezerben nem a tulajdonos lakik a megyeszékhelyen, ez csupán az összes lakott lakás 2 százaléka. 2001 és 2011 között statikusan jellemző városunkra a tulajdonosok által lakott lakások domináns jelenléte és e mellett változatlan a bérlakásokban élők aránya. (KSH, 2011)

\begin{tabular}{|c|c|c|c|c|c|c|c|}
\hline-39 & $40-59$ & $60-79$ & $80-99$ & $100-$ & Összesen & -39 & $100-$ \\
\hline \multicolumn{5}{|c|}{$\mathrm{m}^{2}$ alapterületü lakások száma } & & \multicolumn{2}{|c|}{$\begin{array}{c}\mathrm{m}^{2} \text { alapterüle- } \\
\text { tü lakások } \\
(2001=100.0)\end{array}$} \\
\hline $\begin{array}{c}4046 \\
\mathrm{db}\end{array}$ & $\begin{array}{c}15332 \\
\mathrm{db}\end{array}$ & $\begin{array}{c}10558 \\
\mathrm{db}\end{array}$ & $\begin{array}{c}6606 \\
\mathrm{db}\end{array}$ & $\begin{array}{c}9937 \\
\mathrm{db}\end{array}$ & $46479 \mathrm{db}$ & 108,0 & 128,0 \\
\hline
\end{tabular}

5. sz. tábla: A lakott lakások alapterülete 2011. Forrás: KSH, népszámlálási adatok 2011.

A lakott lakások alapterületi jellemzőit tekintve a legtöbb lakás a KSH adatai alapján 40-59 m2 közötti alapterületü, ez az összes lakott lakás egyharmadát jelenti. A magasabb alapterületü lakások közül a 100 m2-t meghaladó lakások a lakásállomány 22 százalékát teszik ki, ezek főként családi házak kerttel, udvarral. A legkisebb és a legnagyobb alapterületủ lakások esetében tíz év alatt jelen- 
tékeny növekmény a 100 m2-t meghaladó alapterületü lakások esetében érhető tetten, ebben a kategóriában 28 százalékkal épült több lakás 2001 után a városban. A kis alapterületü lakások esetében csekély mértékü növekedés tapasztalható, holott az 1-2 szobás lakások iránti igény a fiatalok, az egy gyermekes, egy szülős, alacsony jövedelemmel rendelkezők körében jelentős.

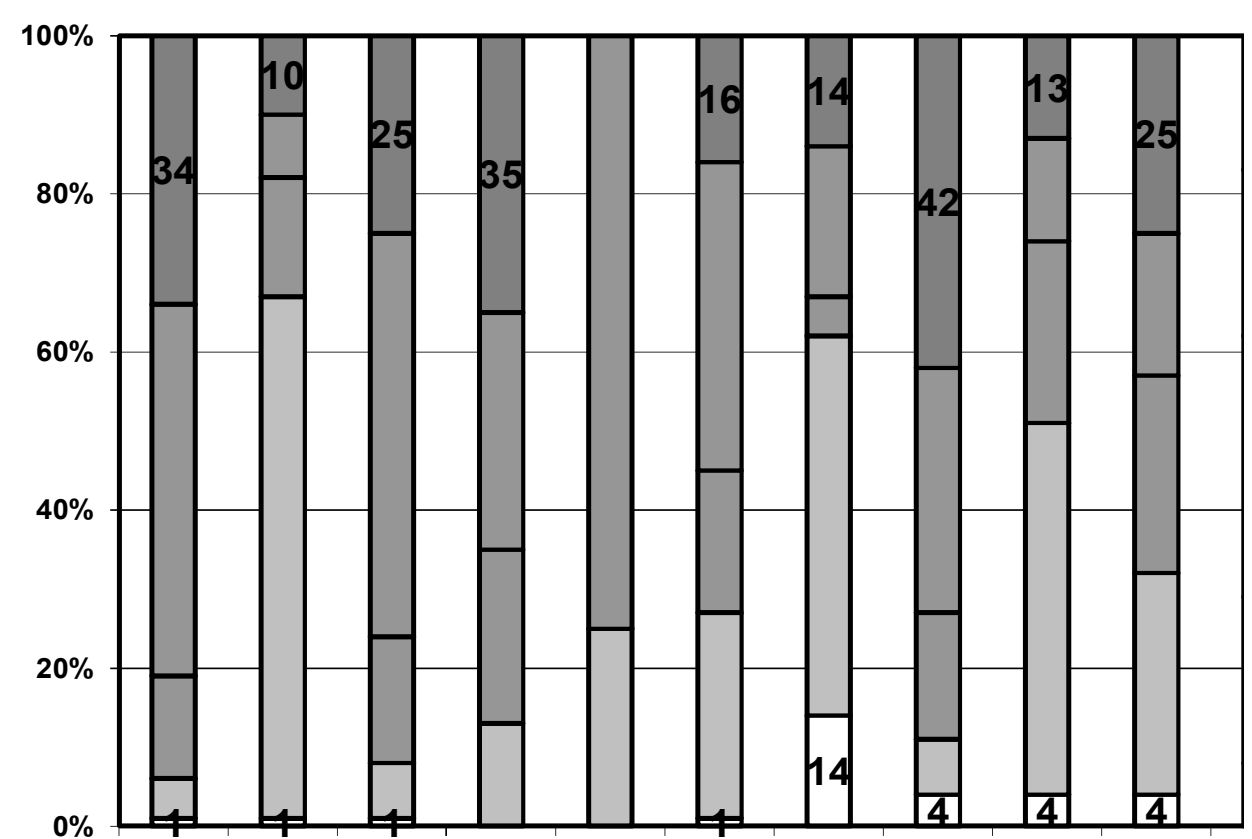

1. sz. ábra: A lakásállomány alapterülete az egyes településrészeken 2012.

Forrás: Nyíregyháza életminősége panelkutatás, 2012.

A panelkutatás adatai alapján az átlagos lakásnagyság a városi lakásállományt tekintve 87 négyzetméter. A lakások mérete az egyes lakókörzetekben változatos, ami a lakókörzetek jellegéből, az ott található lakások építészeti jellegzetességéből adódik.

2010-ben a kertvárosi városrészeken, azaz Oroson, a Kertvárosban, Sóstón, Borbányán és Nyírszőlősön a lakások 50 százaléka $80 \mathrm{~m} 2$ alapterületü, és lakások egyharmadánál a lakás alapterülete a 100 m2-t meghaladja. 2012-ben a megnevezett városrészeken hasonló a lakások mérete. Ezek a zónák kifejezetten családi házas övezetek, ahol az otthon része az udvar, amire nagy alapterületü lakások épülnek. 2010-ben és 2012-ben a jósavárosi lakások 50 százalékának alapterülete kevesebb, mint $50 \mathrm{~m} 2$. A 1,5 és 2,5 szobás panellakások alapterülete változatlan, ezen a városrészen növekedést a városrész permén található családi házaknál tapasztalható. A 35 m2 alatti lakások, ami 1-1,5 szobát jelent lakáson- 
ként, jórészben azokon a városrészeken, ahol panelházak és önkormányzati bérlakások találhatók. A hagyományos panelházak körzeteiben, mint Jósaváros, a kis-alapterületü lakások 8 százalékát teszik ki a körzetben található lakásállománynak. A legrosszabb a helyzet a Huszár telepi lakásoknál mutatkozik, ahol a lakások kétharmadában kevesebb, mint 40 m2-en élnek a családok.

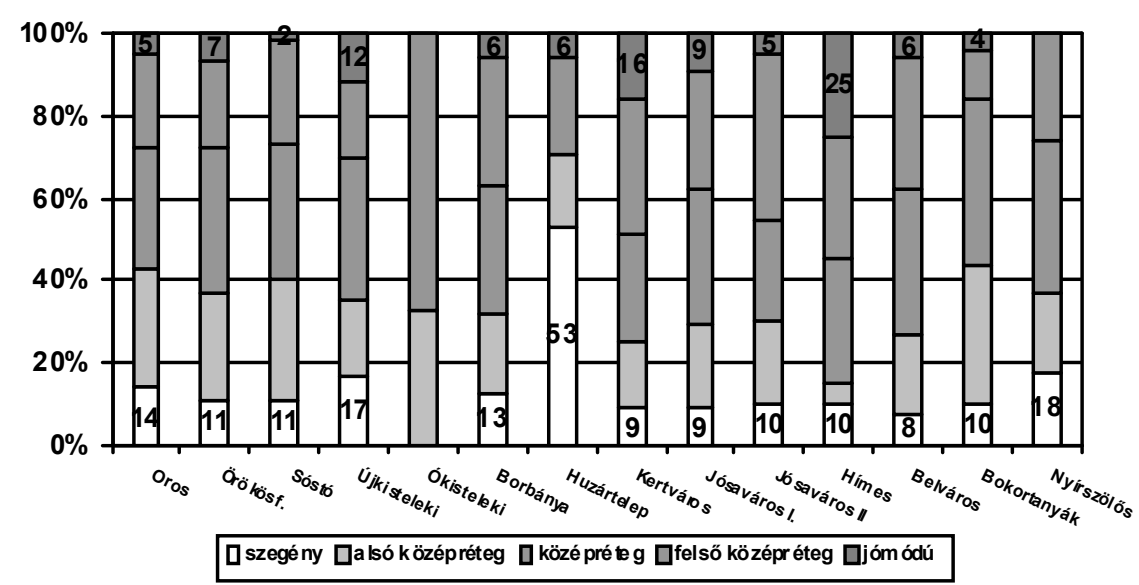

2. sz. ábra: Társadalmi rétegződés a lakókörzetekben. Forrás: Nyíregyháza életminősége panelkutatás, 2012.

2010-ben jövedelmi átlag feletti nettó háztartási jövedelmek voltak mérhetők a kertvárosi városrészekben (Jósaváros II., Borbánya, Oros, Kertváros, SóstóSóstóhegy és Nyírszöllős), az átlag körüli érték jellemezte a belvárost és jóval az alatti nettó háztartásjövedelmek voltak jellemzőek a szegregált lakóterületként ismert Huszár telepen. (Fábián - Takács, 2010)

A társadalmi rétegződés 2012-ben mért adatait vizsgálva szembetűnő, hogy továbbra is a kertvárosi zónákban élnek a felsőközépréteghez és a jómódúakhoz tartozók, addig a Huszár telepen élők 53 százaléka szegénynek tekinthető. Szegénységgel nemcsak a régi huszár laktanya területén találkozunk a városban, hanem a település hagyományosan falusias jegyeket magán hordozó területei közül a Nyírszölősön és Újkistelekiszölőben élők közül megközelítőleg minden ötödik lakos él szegénységben. A lakosság 8-14 százaléka szegény a város többi körzetében, a középréteg a Huszár telep kivételével egyenletesen eloszlik a különböző városrészeken. A jómódú lakosok a város „nyugalmas övezetének” is 
tekinthető Hímesben élnek legnagyobb arányban, ahol minden negyedik lakos anyagilag gondtalan életet élhet. ${ }^{1}$

A társadalmi rétegződés és lakásnagyság kapcsolatát vizsgálva szembetünik, hogy minden társadalmi réteg elöfordul minden lakásméret kategóriában. A szegények jellemzően a 36-80 négyzetméteres lakásokban élnek, ami 1-3 szobás lakást jelent. Az adatokból kitünik, hogy a lakosok nem elsősorban a jövedelmi helyzet alapján élnek az eltérő méretü lakásokban, sokkal inkább a lehetőségek szükössége határolja be az elérhető lakásokat. Ismert jelenség az alacsony lakásmobilitás, a lakosság hosszú időre foglya, és nem cserélője a lakásoknak az életciklusokhoz igazodva.

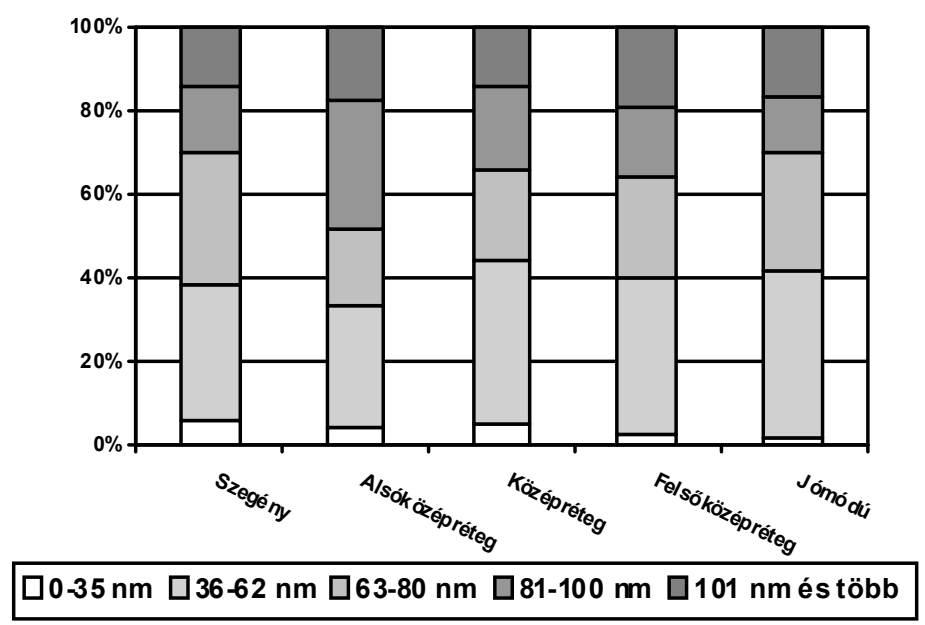

3. sz. ábra: A lakások alapterülete és társadalmi rétegek. Forrás: Nyíregyháza életminősége panelkutatás, 2012.

A lakosság életkori csoportjait tekintve az látszik, hogy a 60 év alatti korosztályokból megközelítően minden ötödik lakos él 100 négyzetmétert meghaladó lakásban. Az aktív korúak egyharmada 36-62 négyzetméter alapterületü lakásokban él, míg a 70 éven felüli lakosok 40 százaléka lakik hasonló méretü lakásokban. Az életkori csoportok adatai is megerösítik azt a tendenciát, miszerint a megszerzett lakás egy életre szól, tulajdon esetén a családok nehezen válnak meg otthonaiktól, a fiatalon és középkorúként elért lakás generációkat szolgál az emberek életében.

\footnotetext{
${ }^{1}$ Szegénynek tekinthetők e vizsgálatban a medián jövedelem 50 százaléka alatt élők. Középréteg a medián jövedelem 80-120 százaléka. Jómódú, akinek a medián kétszeresénél több a jövedelme. (Fábián-Takács, 2010)
} 


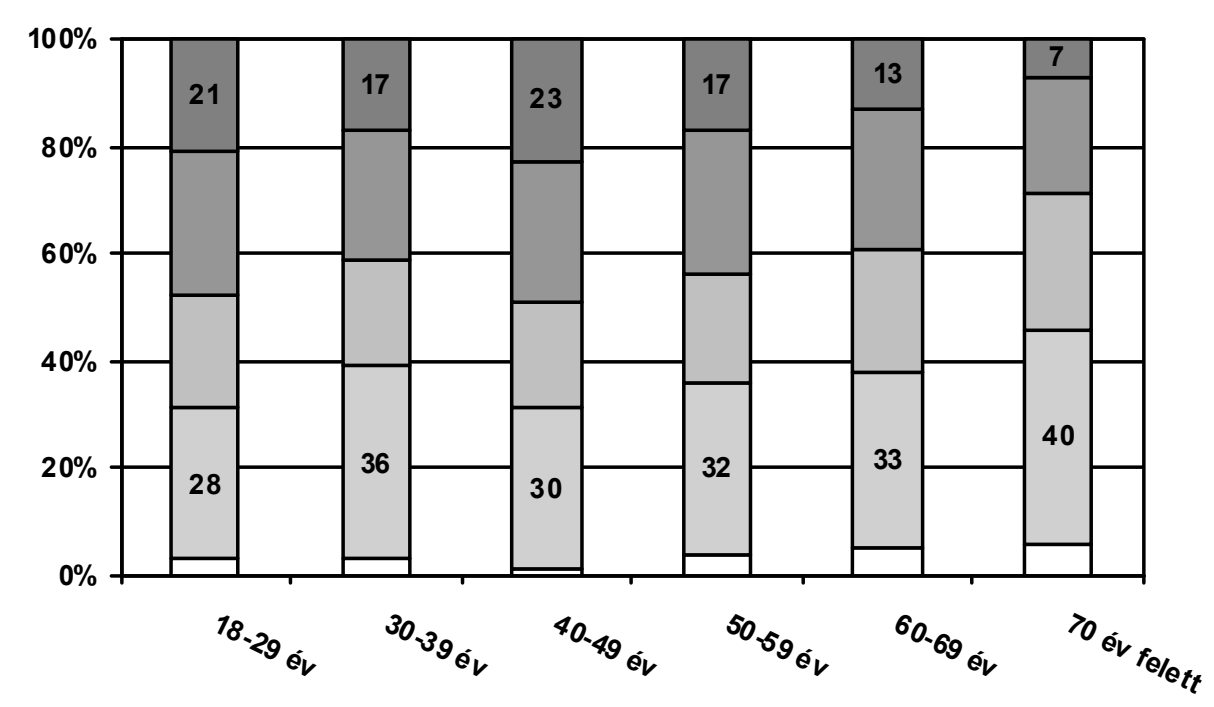

$\square$ 0-35 nm $\square$ 36-62 nm $\square$ 63-80 nm $\square 81-100 \mathrm{~nm} \square^{101} \mathrm{~nm}$ és több

4. sz. ábra: A lakások alapterülete és életkor.

Forrás: Nyíregyháza életminősége panelkutatás, 2012.

A lakások alapterületének vizsgálatába bevonva a háztartás összetétele változót árnyaltabb kép rajzolódik ki a lakáshasználatról. A következő diagramokon követhetjük nyomon az egyes háztartástípusoknál fellelhetö lakásméreteket a városban.

Az egy fős háztartások 40-50 százaléka 36-62 négyzetméter közötti alapterületủ lakásokban él. Ez a lakásméret jellemző egy felnőtt és egy-két gyermek együttélése esetén is. Ezekben a lakásokban általában 2-2,5 szoba található. Ez a lakásméret egy személynek többfunkciós lakóterek kialakítását teszi lehetővé, ahol van nappali és hálószoba, míg két-három együtt élő családtagnak csupán arra alkalmas, hogy a pihenésre szánt terek személyenként elkülönüljenek egymástól. Szembetűnő az adatok elemzésekor az egyszülős családok helyzete, ahol egy felnőttel és két gyermekkel rendelkező háztartások 12 százaléka 35 négyzetméter alatti lakásokban él, 69 százaléka 36-62 négyzetméter alapterületü lakásokban, ahol 2-2,5 szobánál nem áll több rendelkezésre. Az ő esetükben a lakásigény feltehetően több lenne, mint a birtokolt lakásnagysága. 


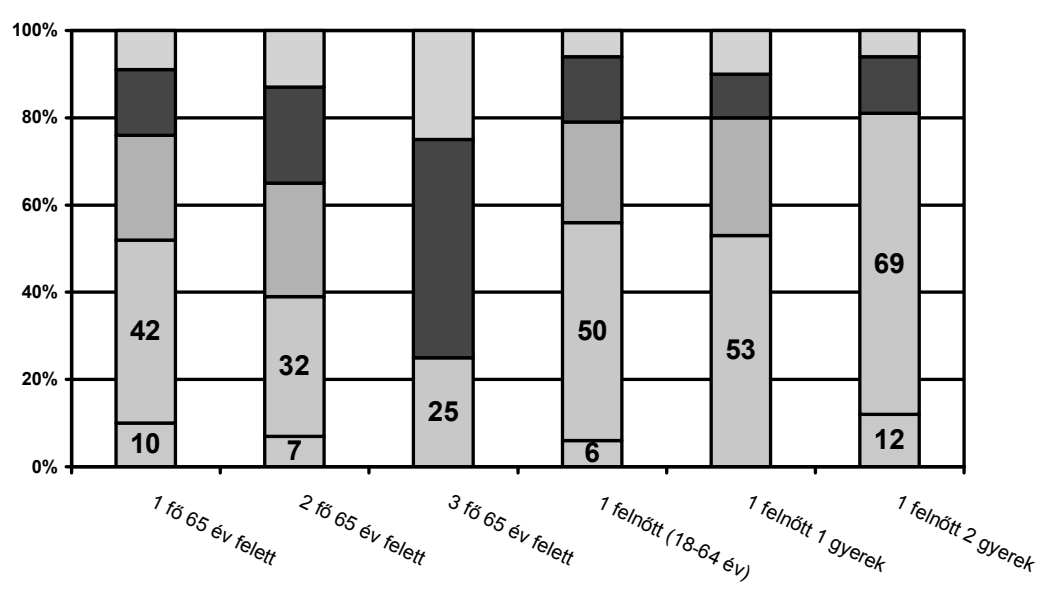

$\square 0-35 \mathrm{~nm} \square 36-62 \mathrm{~nm} \square 63-80 \mathrm{~nm} \square 81-100 \mathrm{~nm} \square 101 \mathrm{~nm}$ és több

5. sz ábra: A lakások alapterülete és a háztartás összetétele (1).

Forrás: Nyíregyháza életminősége panelkutatás, 2012.

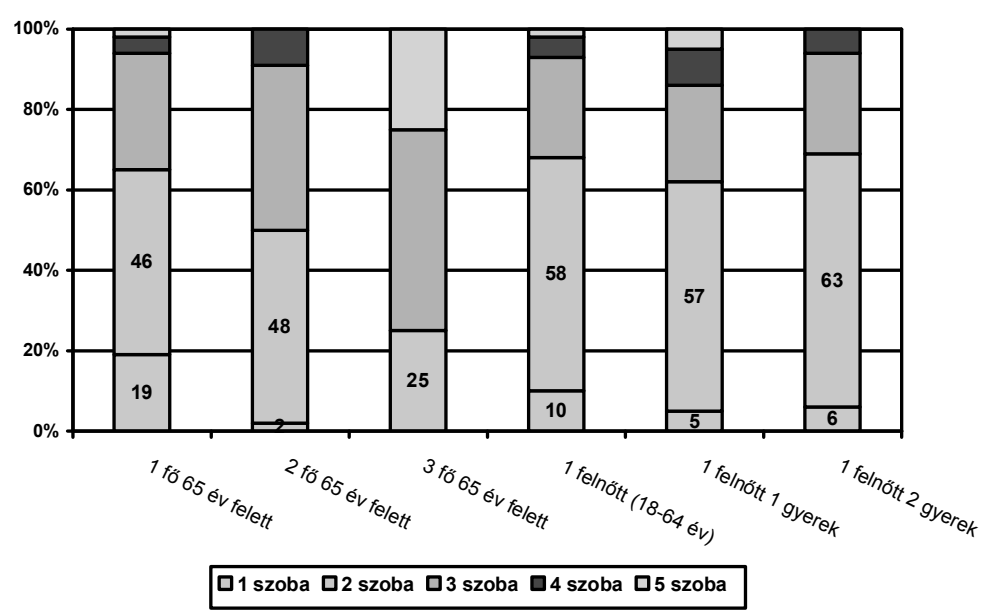

6. sz ábra: Szobák száma és a háztartás összetétele (1).

Forrás: Nyíregyháza életminősége panelkutatás, 2012. 
A lakásméret az együtt élők számának emelkedésével növekszik a városban. A háztartásban élőket tekintve az egy-két felnőtt és gyerek, gyerekek esetében a legfeljebb kétszobás $36-62$ m2 lakások jellemzőek. Kettő felnőtt és kettő vagy ennél több gyermek esetén a lakások alapterülete gyarapodik, nagyobb lakásokban élnek a családok. Ennek ellenére megfigyelhető, hogy a gyerekek számának növekedése nem jelent annyival több szobát a lakásban, hogy mindenkinek legyen saját pihenésre, magánéletre fordítható tere a lakásban.

A KSH 2012. évi jelentése szerint a háztartások a jövedelem 27 százalékát fordítják lakhatási kiadásra. Az Eurostat 2013. évi jelentése szerint hazánkban a háztartások átlagosan a bevételek 24.7 százalékát fordítják havonta lakáskiadásra, rezsire, ezzel a hatodik legdrágább ország vagyunk az Európai Unióban. A szegényeket még ennél is jobban sújtja a lakáskiadásra fordított összeg, mivel esetükben a háztartás jövedelmének 34 százaléka fordítódik a lakhatás költségeire. (Habitat for humanity, 2013)

A nyíregyházi panelkutatás előző adatfelvételekor vizsgált adatok arra engedtek következtetni, hogy a lakosság háromnegyede nézett már szembe fizetési problémával a lakás költségeit tekintve. Rendszerint a fizetési elmaradás átmeneti, felhalmozott adóssága a lakosság egyötödének volt 2010-ben. (Szoboszlai, 2010.) A lakásfenntartás költségeinek kifizetése azokban a háztartásokban jelent gondot, ahol több inaktív hozzátartozó él a háztartásban, mint munkajövedelemmel rendelkező felnőtt személy. Különösen a tartós munkanélküli, gyermekes családoknál és az egyedül élő 65 év felettieknél jelentkezik hátralék a lakásköltségek kifizetésében, ha a lakás költségei meghaladják az egyén jövedelmének egynegyedét.

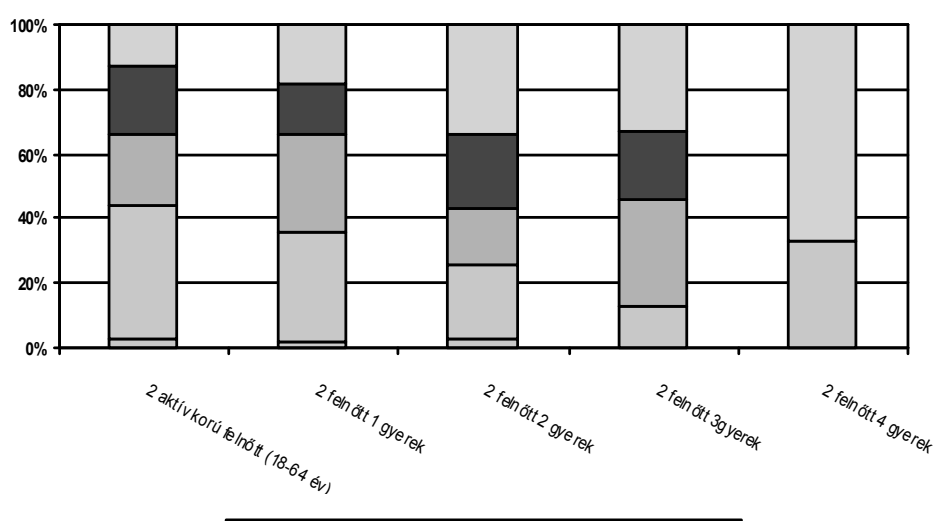

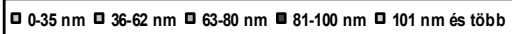

7. sz. ábra: A lakások alapterülete és a háztartás összetétele (2).

Forrás: Nyíregyháza életminősége panelkutatás, 2012. 


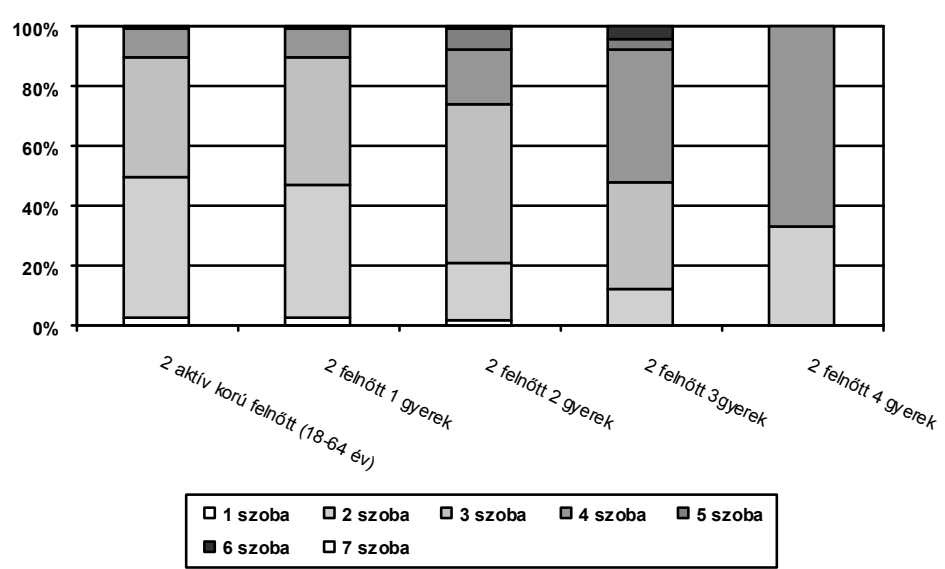

8. sz. ábra: Szobák száma és a háztartás összetétele (2).

Forrás: Nyíregyháza életminősége panelkutatás, 2012.

Három felnőtt és gyerek, illetve gyerekek együtt élése esetén eltünnek a kis alapterületü, egy szobás lakások. A családok jellemzően 80 négyzetméter feletti alapterületü lakásokban élnek, ahol többnyire 3 szoba található. Ezek a lakások családi házas övezetekben épültek, ahol az együtt élők számát és a szobák számát tekintve elegendő lakó-és élettér jut a családtagoknak.

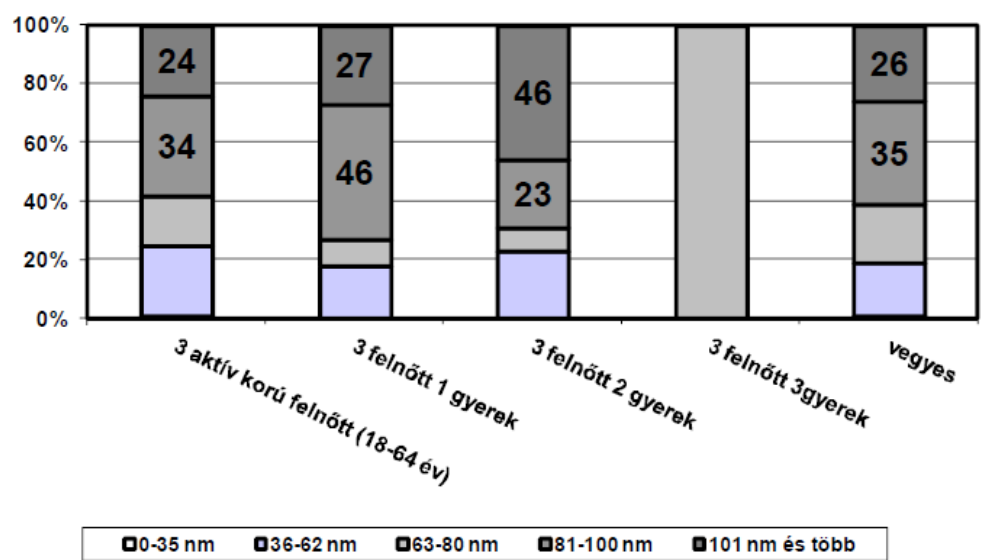

9. sz. ábra: A lakások alapterülete és a háztartás összetétele (3).

Forrás: Nyíregyháza életminősége panelkutatás, 2012. 


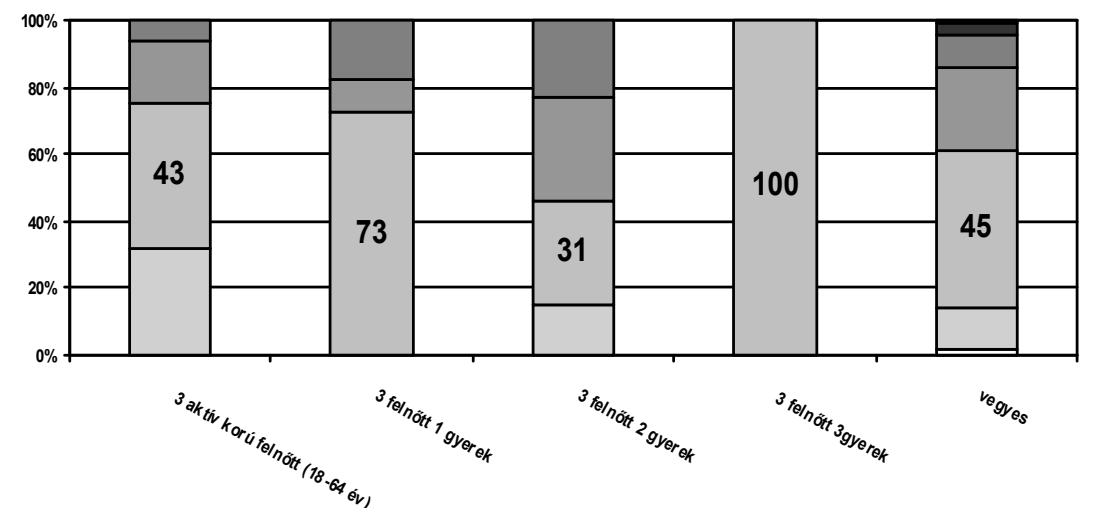

\ 1 szoba $\square 2$ szoba $\square 3$ szoba $\square 4$ szoba $\square 5$ szoba $\square 6$ szoba $\square 7$ szoba

10. sz. ábra: Szobák száma és a háztartás összetétele (3).

Forrás: Nyíregyháza életminősége panelkutatás, 2012.

\section{A bérlakásállomány jellemzői}

A szociális bérlakások jellemzően Budapesten és a megyei jogú városokban koncentrálódnak, ahol a bérlakások 69 százaléka található. Budapesten 5,8 százalék, a megyei jogú városokban 5,1 százalék az önkormányzati bérlakások aránya. (Hegedüs és mtsai 2009, KSH, 2009.) Nyíregyházán a lakásprivatizációval az önkormányzati bérlakás állomány a rendszerváltás idején 18 százalékról 4,4 százalékra csökkent. A város az elmúlt húsz évben bővítette a kezelésében lévő bérlakások számát, így számottevő elmozdulást jelent a 4,4 százalékról 7,5 százalékra megnövekedett önkormányzati lakások aránya a lakásállomány egészét tekintve.

A nyilvántartott önkormányzati bérlakások száma megközelítően $2.000 \mathrm{db}$ volt 2002-ben, a lakások 56 százaléka összkomfortos, 23 százaléka komfortos, 6 százalék félkomfortos, 15 százalék komfort nélküli és 1 százalék szükséglakás. (Nyíregyháza Megyei Jogú Város, 2003.) Tíz év alatt sem történt lényegi változás a szociális bérlakások számában. A bérlakásokat kezelő NYÍRVV Kft adatai alapján 2011-ben 1939 db bérlakás volt, 2013-ban tízzel kevesebbet 1929 db önkormányzati bérlakást tartottak nyilván a városban, melyek közül 150 lakás 
üresen állt. A bérlő nélküli lakások közel fele nem hasznosítható, másik fele felújítás alatt állt. ${ }^{2}$

\begin{tabular}{|l|c|}
\hline \multicolumn{1}{|c|}{ Városrész } & $\mathrm{db}$ \\
\hline Belső lakóterület, Nagykörút által határolt terület & 465 \\
\hline Érkerti lakótelep & 177 \\
\hline Örökösföldi lakótelep & 300 \\
\hline Jósaváros, Stadion környéke & 542 \\
\hline Huszár lakótelep & 290 \\
\hline Keleti lakótelep & 125 \\
\hline $\begin{array}{l}\text { Egyéb: Sóstó-Sóstóhegy, Malomkert, Butyka, Bokortanyák, } \\
\text { Borbánya, Kisteleiszőlő }\end{array}$ & 40 \\
\hline Összesen & $\mathbf{1 9 3 9}$ \\
\hline
\end{tabular}

6. sz. táblázat: A bérlakások területei elhelyezkedése Nyíregyházán. Forrás: Nyíregyháza Megyei Jogú Város, 2011.

A bérlakások területi eloszlását tekintve a bérlakások többsége panelépítésü lakás, melyek életkora meghaladja a harminc évet. Ennek ellenére ezek a lakások összkomfortos, távhővel fütött lakások. Közel sem ennyire kényelmesek a lakások a város két szegénytelepén, a Huszár telepen és a Keleti lakótelepen. Mindkét területen komfort nélküli, szükséglakás besorolású lakások található. 2014-ben elkezdődött 70 lakás külső homlokzatának felújítása, tetőjavítás, külső nyílászárók cseréje Európai Uniós támogatásból a Huszár telepen. A program azonban nem tartalmaz fütés beépítést, belső felújítást a lakásokban. A többi lakás rekonstrukciója egyelöre nincs tervben az önkormányzatnál. A Keleti lakótelep szükséglakásainak lebontása rendre napirenden van az önkormányzatnál, azonban 125 bérlö és családja sorsa jelenleg nem megoldott e kérdésben.

\begin{tabular}{|l|c|}
\hline \multicolumn{1}{|c|}{ Komfort fokozat } & $\mathrm{db}$ \\
\hline Összkomfortos & 1275 \\
\hline Komfortos & 293 \\
\hline Félkomfortos & 168 \\
\hline Komfort nélküli & 203 \\
\hline Összesen & $\mathbf{1 9 3 9}$ \\
\hline
\end{tabular}

7. sz. táblázat: Önkormányzati bérlakások Nyíregyházán komforzat szerint Forrás: Nyíregyháza Megyei Jogú Város, 2011.

\footnotetext{
${ }^{2}$ Kezdődnek a lakáskiutalások. http://www.nyiregyhaza.hu/kezdodnek-alakaskiutalasok.
} 
Nem mehetünk el szó nélkül a mellett a tény mellett, hogy az önkormányzati bérlakásra több igénylő van, mint amennyit képes kielégíteni a város a tulajdonában lévő lakásokból. Nyíregyházán bérlakásra föként fiatal házas és 40 év alatti gyerekes családok várnak, akik a piaci áron kínált bérlemény helyett önkormányzati bérlakásban élnének, ha tehetnék.

\begin{tabular}{|l|c|}
\hline \multicolumn{1}{|c|}{ Szobák száma } & $\mathrm{db}$ \\
\hline 1 szobás & 967 \\
\hline 1,5 szobás & 219 \\
\hline 2,5 szobás & 108 \\
\hline 3 szobás & 51 \\
\hline 3 szobától több & 28 \\
\hline
\end{tabular}

8. sz. táblázat: Önkormányzati bérlakások Nyíregyházán szobák száma alapján. Forrás: Nyíregyháza Megyei Jogú Város, 2011.

Gyermekes családoknak nagyon kevés az a lakóterület, ami a bérlakások nyolctizedében jut számukra. Ezek a 1-1,5 szobás lakások nem jelentenek elegendő életteret a gyermekeknek és a felnőtteknek, e miatt zsúfoltak.

A bérlakás jellemzőket alapul véve felfedezhető a lakhatási szegénység a bérlakásban élők esetében. A Habitat for Humanity lakhatást kutató szervezet szerint a " lakhatási szegénység olyan lakáskörülményeket jelent, amelyek között nem teljesülnek a megfelelö lakás kritériumai, igy pl. megfizethetöségi problémák, alapszolgáltatásokhoz és infrastruktúrához való hozzáférés hiánya, minöségi vagy mennyiségi értelemben nem kielégitö lakás (kis alapterület, megfeleló fütés hiánya, elmaradt felújitások stb.), rossz elhelyezkedésü lakás (pl. szolgáltatásokhoz, infrastruktúrához való rossz hozzáférés, rossz szociális környezet)." Ez különösen jellemző a komfort nélküli, korszerütlen, kis alapterületü, szükséglakásokkal rendelkező szegény negyedekben Nyíregyházán.

\section{A lakások felszereltsége}

A 2011. évi népszámlálási adatokból kitünik, hogy a megyeszékhelyen található lakások közmüellátottsága jónak mondható. Vízvezeték a lakások 98 százalékában, meleg folyóvíz 96 százalékban, vízöblítéses WC 97 százalékban van a megyeszékhely lakásaiban. Egyedül a közcsatorna marad el az előbb említett adatoktól, itt ugyanis a közellátás a lakások 85 százalékára jellemző. (Forrás: KSH, 2011. évi népszámlálási adatok) 


\begin{tabular}{|c|c|c|c|c|c|c|}
\hline $\begin{array}{c}\text { Lakás db } \\
\text { / százalék }\end{array}$ & $\begin{array}{c}\text { Összkom- } \\
\text { fortos }\end{array}$ & $\begin{array}{c}\text { Kom- } \\
\text { fortos }\end{array}$ & $\begin{array}{c}\text { Félkom- } \\
\text { fortos }\end{array}$ & $\begin{array}{c}\text { Komfort } \\
\text { nélküli }\end{array}$ & $\begin{array}{c}\text { Szzükség és } \\
\text { egyéb lakás }\end{array}$ & $\begin{array}{c}\text { Össze- } \\
\text { sen }\end{array}$ \\
\hline $\mathrm{db}$ & 38896 & 10006 & 735 & 1428 & 209 & 51274 \\
\hline százalék & 75,8 & 19,5 & 1,4 & 2,8 & 0,5 & 100 \\
\hline
\end{tabular}

9. sz. tábla: A lakások komfortossága.

Forrás: KSH, 2011. évi népszámlálási adatok.

A városban található lakások háromnegyede összkomfortosnak tekinthető, vagyis a lakásban található fürdőszoba, WC, melegvíz és központi fütés. A lakások minősége többségében a kor színvonalának megfelelő a városban. A lakásállomány egyötöde komfortos, ettől rosszabb minőségü lakás az 5 százalékot közelíti. Figyelemre méltó, hogy a városban 209 lakás besorolása szükséglakás. A legrosszabb a lakások komfortja a város szegénytelepein, az önkormányzati bérlakásokban. A közeljövőben érzékelhető változást jelenthet a Huszár telepi lakások egy részének felújítása a városrész rehabilitációs programban, ahol az utak rendbetétele mellett a lakások közmüellátottságán és komfortfokozatán is javítanak.

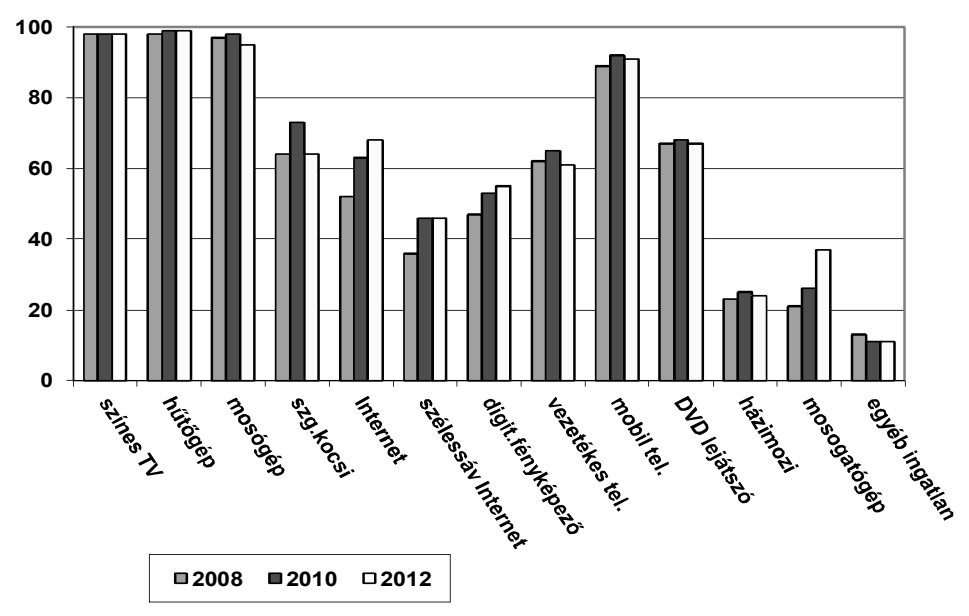

11. sz. ábra: Eszközök a lakásban az előfordulás százalékában.

Forrás: Nyíregyháza életminősége panelkutatás, 2008, 2010 és 2012.

A lakások a modernkor igényeit kielégítő eszközökkel való ellátottságában csekély változás tapasztalható 2008 és 2012 között. (Szoboszlai - Takács, 2008 és 
Szoboszlai, 2010) Az alapeszköznek tekinthető színes televízió, hütőgép és mosógép nagyon kevés kivételtől eltekintve minden háztartásban megtalálható a városban. Növekedés az Internet elérésben és a mosogatógép használatában tapasztalható a két évvel ezelőtti adatokhoz képest. Változatlan maradt a szélessávú Internethez való hozzáférés városrészek közötti eltérése. Kismértékủ csökkenés tapasztalható a mobil-és vezetékes telefonok használatában, mobil telefonnal egyharmadnyi háztartással több háztartás rendelkezik, mint a vezetékessel.

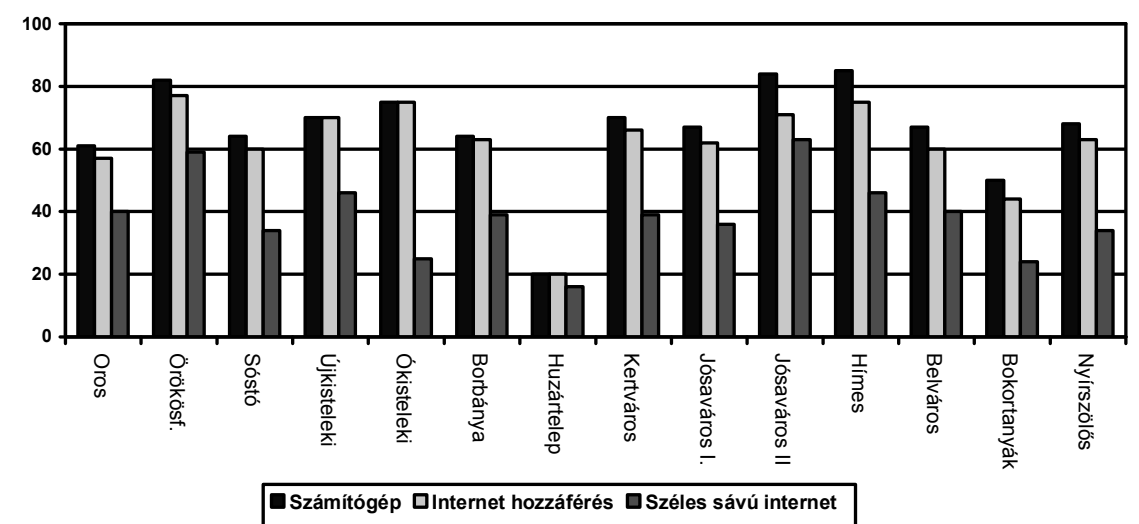

12. sz. ábra: Infokommunikációs eszközök a város körzeteiben.

A városkörzetek adatait vizsgálva szembetünő az egyenlötlenség az infokommunikációs eszközök birtoklásában a város különböző területein élők esetében. Amíg számítógép és Internet hozzáférés a háztartások kétharmadában van, addig jóval kevesebb háztartásban biztosított a szélessávú Internet elérés. Ezeknek az eszközöknek a beszerzése és előfizetése a szolgáltatók versenyhelyzete ellenére is költséges, emiatt az eszközök föként azokban a háztartásokban találhatók, ahol a jövedelemből képesek ezeket megfizetni. A Huszár telepen a legrosszabb a háztartások felszereltsége, itt csupán minden ötödik háztartásban található számítógép és Internet csatlakozás. A szegregátumban élők hozzáférése erősen korlátozott az infokommunikációs eszközökhöz, ami leginkább a jövedelmi szegénységnek és az Internet elérés technológiai akadályainak tudható be. A modern információs eszközök nélkülözése miatt Interneten megjelenő információkból és szolgáltatásokból rekesztődnek ki az itt élők. 


\section{Összegzés}

A lakóhely és a lakásjellemzők tekintetében lényeges változásokról nem tudunk beszámolni a megyeszékhelyen a 2008-as és 2010-es kutatáshoz képest 2012ben. A lakásállomány szerkezetében érzékelhető fejlödés nem történt az elmúlt két évben. A lakásállomány növekedés szerény mértékü, e mellett a bérlakások tekintetében kis léptékü bővülésről sem lehet beszámolni. A bérlakásokban élők esetében a lakhatási szegénységgel kell szembe nézni, mivel ezek a lakások kis alapterületük miatt a gyerekes családoknak zsúfoltak. További gondot jelentenek a lakhatási szegénységet tekintve a szegény negyedek korszerütlen, kis alapterületü szükséglakásai. A lakások egy részének felújítása elkezdődött, a többi még várat magára. Fejlödés a lakások felszerelését tekintve az infokommunikációs eszközök használatában és köztük az Internettel való ellátottság 5 százalékos emelkedésében érzékelhető két év alatt. Ez a jövőben tovább emelkedhet a szolgáltatók közötti verseny és új eszközök megjelenésével.

\section{Felhasznált irodalom}

1. 2011. évi Népszámlálás. Területi adatok. Szabolcs - Szatmár - Bereg megye. Letöltési hely: http://www.ksh.hu/docs/hun/xftp/idoszaki/nepsz2011/nepsz_03_16_2011.pdf

2. Fábián Gergely - Takács Péter: A jövedelmi egyenlőtlenségek változásai és a szegénység. Életminőség Nyíregyházán (Fábián, Patyán, Huszti szerkesztette) Debreceni Egyetem Egészségügyi Kar, 2012.

3. Hegedüs József - Eszenyi Orsolya - Somogyi Eszter - Teller Nóra: Lakhatási szükségletek Magyarországon. Városkutatás Kft, 2009.

Letöltési hely: www.mut.hu/?module=news\&action=getfile\& fid $=114874$

4. Koltai Luca szerkesztette (2014): Éves jelentés a lakhatási szegénységről 2013. Habitat for humanity.

Letöltési hely: http://www.habitat.hu/files/Lakhatasi_Jelentes_2013_hosszu.pdf

5. KSH, Megyei jogú városok, 2012. július.

Letöltési hely: http://www.ksh.hu/docs/hun/xftp/idoszaki/regiok/veszpremmjv10.pdf

6. Lakásviszonyok az ezredfordulón. KSH, Budapest, 2005. Letöltési hely: http://mek.niif.hu/06900/06979/06979.pdf

7. Népszámlálási adatok, 2011 Letöltési hely: http://www.ksh.hu/nepszamlalas/tablak_teruleti_15

8. Nyíregyháza Megyei Jogú Város Esélyegyenlőségi program 2011-2016. 
Letöltési hely:

http://adat.nyiregyhaza.hu/adattar/2011/hatarozat/110707_H_127.pdf

9. Nyíregyháza Megyei Jogú Város Településrendezési Terv, 2003. 4.7. A lakásellátás és lakóterületek rendezési javaslata

Letöltési hely:

http://www.jatekhirek.hu/documents/4alatamaszto/4_7f_lakas.pdf

10. Szoboszlai Katalin: Lakásjellemzők Nyíregyházán $2008-2010$. Életminőség Nyíregyházán (Fábián, Patyán, Huszti szerkesztette) Debreceni Egyetem Egészségügyi Kar, 2012.

11. Szoboszlai - Takács: Lakóhely és lakásjellemzők Nyíregyházán. Szabolcs Szatmár - Beregi Szemle 2010/3, p. 343 - 554.

Szoboszlai Katalin: főiskolai docens

Debreceni Egyetem Egészségügyi Kar, 4400 Nyíregyháza, Sóstói u. 2-4. 